Adriana Adamska*

Kraków

\title{
Anioł jako przewodnik wychowawcy
}

\author{
Aniołowie nie przestanq istnieć, \\ jeśli my przestaniemy w nie wierzyć, \\ lecz nie będa mogły stać się częścia \\ naszej rzeczywistości, \\ jeśli się przed nimi zamkniemy.
}

G. Mallasz ${ }^{1}$

Nauka o aniołach jest integralną częścią doktryny chrześcijańskiej. Przekazane mieszkańcom cywilizacji euroatlantyckiej objawienie zawarte w Biblii zbudowało fundament tej kultury. Gdyby usunąc z kart Pisma Świętego aniołów, powstałby zupełnie nowy, niepodobny do oryginalnego tekst. Nikt nie kwestionuje prawd objawionych, gdyż tylko one, w przeciwieństwie do ludzkich dociekań, są wolne od błędu. Dlatego właśnie nie można także zaprzeczyć obecności aniołów, ponieważ mówi o nich sam Bóg.

„Nie powinniśmy spekulować na temat aniołów, lecz badać świadectwa zawarte w Piśmie Świętym. Aniołowie nie są urojeniem, lecz rzeczywistością" pisał J. Calvin ${ }^{2}$. W świetle badań socjologicznych zasięg wiary w aniołów jest o wiele większy niż w przypadku innych postaci biblijnych ${ }^{3}$. Badania dowodzą,

* Dr Adriana Adamska, adiunkt w Katedrze Edukacji Artystycznej Wyższej Szkoły Filozoficzno-Pedagogicznej „Ignatianum” w Krakowie.

${ }^{1}$ Zob. G. Mallasz, Die Engel erlebt, Zurych 1983, s. 157, (cyt. za: K. Scherer, Powierzyt Cię Aniołom swoim, tłum. N. Stelmaszyk, Poznań 2005, s. 67).

${ }^{2}$ Zob. K. Scherer, dz. cyt., s. 66.

${ }^{3}$ Zob. I. Borowik, Procesy instytucjonalizacji $i$ prywatyzacji religii $w$ powojennej Polsce, Kraków 1997, s. 117, 183; A. Potocki, Aniołowie dobrzy i źli w doświadczeniu społecznym, w: H. Oleschko (red.), Księga o Aniołach, Kraków 2002, s. 306-307. 
że wiara w świat aniołów jest wrodzoną potrzebą człowieka. Tkwi ona w ludziach wszystkich epok i szerokości geograficznych, albowiem wiedza na temat aniołów nie jest przypisana wyłącznie doświadczeniu chrześcijan. Przejawiał ją już antyk, ujawniając wiarę w duchy opiekuńcze. Słynny Arystoteles (IV wiek przed Chrystusem) - filozof, ale także pedagog Aleksandra Wielkiego, pouczał swego podopiecznego: „Izali nie wiesz, że wedle Hermogena, dwa duchy opiekuńcze strzegą ciebie - jeden z prawej, drugi z lewej strony? One opiekują się tobą, czuwają nad twymi sprawami, wszystko, co czynisz, przedstawiają Stwórcy twemu. Przyznaj, Aleksandrze, czy ich obecność nie powinna cię wstrzymać od wszystkiego, co niegodne, co nikczemne?"4.

Istoty podobne do tych występujących w Biblii znane były w starożytnym Egipcie, Mezopotamii, Azji Mniejszej, w wielkich religiach Dalekiego Wscho$\mathrm{du}, \mathrm{w}$ rozwiniętych kulturach przedkolumbijskiej Ameryki oraz, jak wskazuje powyższy przykład - w przedchrześcijańskiej Europie ${ }^{5}$.

„Obecność aniołów jest negowana przez racjonalizm myślenia współczesnego człowieka, a zarazem zmusza go do zastanowienia się, gdyż poprzez ich umitologizowanie przeżywa on głębokie wypalenie swoich duchowych wartości, których pełnej dojrzałości właśnie tak bardzo pragnie" - pisze K. Scherer6. Świadomość dotycząca obecności aniołów występuje najsilniej w świecie dziecka. Dorośli zatracają wiarę w istnienie tych nadprzyrodzonych duchów, jednak automatycznie pojawia się ona w sytuacjach związanych z różnego typu niemożliwymi do uzasadnienia z racjonalnego punktu widzenia, ratującymi życie lub „tylko" zdrowie interwencjami. Ponadto w ostatnim czasie eksplozja prądu New Age przyniosła ze sobą renesans zainteresowania aniołami. I tak zlaicyzowny świat zachodniej Europy ponownie zachwyca się i odkrywa ich obecność, gdyż - jak tłumaczy znany benedyktyński terapeuta ojciec A. Grün - mieszkańcy tej części świata intensywnie poszukują tego, co przekraczałoby banalność ich życia $^{7}$. W zjawisku tym zawarta jest głęboka prawda na temat konstytucjonalnej pozycji bytu ludzkiego, która sięga swymi korzeniami prawdy biblijnej, a ponownie w genialny sposób zdiagnozowana została w IV wieku po Chrystusie przez jednego z największych umysłów chrześcijańskiej starożytności - świętego Augustyna: „Uczyniłeś nas Boże dla siebie i niespokojne jest serce nasze dopóki nie spocznie w Tobie" 8 .

Najwyraźniej anioł jest łatwiej przyswajalny dla ludzi, choć faktem jest to, że nie można postrzegać aniołów w oderwaniu od źródła ich mocy i piękna Boga Samego. Wskazuje na to sama ich definicja. Tak właśnie dzięki aniołom

${ }^{4}$ Zob. M. Fryszkiewicz, Rzecz o Aniołach pomiędzy Bogiem a człowiekiem, Marki-Struga 1993, s. 11.

${ }^{5}$ Zob. H. Oleschko, Aniołów dyskretny lot, Kalwaria Zebrzydowska 1996, s. 13.

${ }^{6}$ Zob. K. Scherer, dz. cyt., s. 69.

${ }^{7}$ Zob. A. Grün, Każdy ma swego anioła, tłum. K. Zimmerer, Kraków 2002, s. 5.

${ }^{8}$ Zob. św. Augustyn, Wyznania I, I. 
wkracza w powierzchowną ludzką codzienność to, co nadprzyrodzone, kojąc tę bardziej lub mniej uświadomioną za Nim tęsknotę.

„Otwartość na działanie Boga poprzez Jego «duchy służebne», poprzez aniołów, wzbogaca przeżycia duchowe o ich pozytywny wpływ na codzienne kształtowanie naszego życia" - pisze K. Scherer. Współczesny, osamotniony w zalewie konsumpcyjnych propozycji i naznaczony piętnem dysfunkcyjnych relacji rodzinnych, człowiek, jak mało który przedstawiciel ludzkiego rodzaju na przestrzeni historii pragnie miłości i sympatii. Istotą istnienia aniołów jest ich miłość, dlatego trudno odnaleźć lepszy adres, by uspokoić swoje pragnienie. Wszystko to, co dotyczy ludzi, nie jest aniołom obojętne. Ich powołaniem jest przyjaźń.

„Doświadczenie obecności aniołów staje się możliwe poprzez gotowość odrzucenia sceptycyzmu i otwarcie się na ich spotkanie” - pisze K. Scherer ${ }^{10}$. „Fakt, że człowiek współczesny nie ma świadomości, a raczej nie ma pełnej świadomości istnienia i potęgi aniołów, nie jest w stanie zniweczyć ich egzystencji, zniweczyć ich mocy. Przeciwnie, ignorancja ta powoduje zubożenie ducha ludzkiego, usypia go, wystawia na poważne niebezpieczeństwa, a równocześnie pozbawia go potężnej mocy" - uważa J. Wagner i odwołuje się do następującego porównania: Energia atomowa istniała od początku stworzenia świata materialnego, długo przed momentem, w którym człowiek zaczął podejrzewać jej istnienie. Ta obojętność, jego zdaniem, nie jest bynajmniej postępem. Ignorując istnienie aniołów, ludzie tracą wiele na wszystkich płaszczyznach bytu oraz polach swojej aktywności ${ }^{11}$.

„To nie gwiazdy zgasły, ale człowiek przestał je widzieć”. Tam, gdzie jest obecny człowiek, obecny jest również anioł, mimo że ten rzadko jest tego świadomy. P. Bosman uważa, że aniołem jest ktoś, „kogo Bóg przysyła w twoje życie, nieoczekiwanie i niezasłużenie, aby ci zapalił kilka gwiazd, gdy jest całkiem ciemno" ${ }^{\prime 2}$. Do tej roli powołany jest każdy wychowawca.

\section{Propozycja dla pedagoga}

Anioł to człowiek bez śmiertelności. Paracelsus $^{13}$

Zdarza się niekiedy, że podopieczni wypowiadają się o swoim wychowawcy: Nasza Pani/nasz Pan jest jak anioł! Mówi się także często o anielskiej cierpliwości, która niewątpliwie potrzebna jest każdemu z pedagogów. Bycie pedagogiem,

\footnotetext{
${ }^{9}$ Zob. K. Scherer, dz. cyt., s. 69.

${ }^{10}$ Zob. Tamże, s. 68.

${ }^{11}$ Zob. G. Huber, Mój aniot pójdzie przed tobq, thum. J. Drozd, Miejsce Piastowe 1982,

${ }^{12}$ Cyt. za: A. Grün, dz. cyt., s. 13.

${ }^{13}$ Tamże, s. 64.
} s. 36 . 
jak mało która profesja, wymaga nieustannej konfrontacji z postawą wszechogarniającej wychowanków miłości. Jedynie działanie zrodzone na płaszczyźnie miłości ma siłę wygenerować pozytywnie prognozujące skutki wychowawcze. Niestety, problemy młodzieży oraz ich inwencja w każdym czasie poddają zasób metod pedagogicznych ciężkiej próbie, równocześnie mobilizując kreatywność wychowawców w kierunku poszukiwania nowych rozwiązań. Niejednokrotnie w tych poszukiwaniach zdarza się, że pomijane bywają rozwiązania najprostsze. Wspomniał już o tym papież Pius XI w swojej encyklice „O chrześcijańskim wychowaniu młodzieży”, pisząc, że „ludzie, stworzeni od Boga na obraz i podobieństwo Jego, są przeznaczeni na to, żeby kiedyś znaleźli szczęście w posiadaniu samego Boga, tego dobra najdoskonalszego". Niemniej, ci sami ludzie ignoruja ten fakt i pragną szukać metod osiąnięcia szczęścia w tym świecie oraz metod rozwiązywania problemów drogą własnych koncepcji. Pragnienie życia doskonalszego, w stronę którego dąży każdy człowiek, gdyż zaszczepione zostało ono przez Samego Stwórcę, pragną oni realizować, posługując się wyłącznie ludzką strategią środków - „kładąc przesadnie nacisk na etymologiczne znaczenie wyrazu «edukacja», chcieliby taką doskonałość wydobyć z samej ludzkiej natury i dojść do niej wyłącznie naturalnymi siłami. I w tym tkwi ich błąd"14.

Wychowanie musi obejmować całego człowieka, także jego warstwę duchowa, gdyż jest ona jego istotną częścią składową, a pominięcie jej jest poważnym zubożeniem w rozwoju człowieczeństwa. Formowanie tej sfery nie leży wyłącznie w gestii katechety, dotyczy każdego pedagoga, dla którego przestrzeń rzeczywistości nadprzyrodzonej nie jest abstrakcją. Cywilizacja Europy została zbudowana na fundamencie chrześcijaństwa, dlatego też w kraju, w którym 90\% społeczeństwa uważa się za chrześcijan, nie powinna być żadną aporią metoda pedagogiczna, odwołująca się w swojej praktyce do wzywania pomocy aniołów. Wspomniany wyżej papież Pius XI sam miał zwyczaj zwracać się często do swego anioła stróża i także innym zalecał tę praktykę, a zwłaszcza dyplomatom, misjonarzom, wychowawcom: „Zalecamy to nabożeństwo zawsze ludziom światłym. Niech nie zapominają o tym, że mają przy sobie niebieskiego przewodnika, niech pamiętają, że anioł Boży istotnie czuwa nad nimi. Ta myśl doda im odwagi i ufności”"15.

Tam, gdzie jest człowiek, tam również jest jego anioł stróż. Stoi najbliżej. Modlitwa adresowana do aniołów stróżów własnych podopiecznych przydatna jest zwłaszcza w sytuacjach, kiedy inne metody nie są skuteczne, a pedagog czuje swoją bezradność. Podstawową jej cechą jest zaufanie w skuteczność mocy nadprzyrodzonej, przewyższającej ludzkie możliwości, jaką dysponują te dobre niewidzialne istoty. Aby jednak mogło rozwinąć się tego typu zaufanie, koniecz-

${ }^{14}$ Zob. Pius XI, Divini illius magistri. Encyklika o chrześcijańskim wychowaniu młodzieży, Poznań 1931, s. 6-7.

${ }^{15}$ Tenże, Przemówienie z dnia 10.06.1923 do inteligencji katolickiej. Discorsi di Pio Xi, vol. I, 141 (cyt. za: G. Huber, dz. cyt., s. 17). 
na jest najpierw wiedza o aniołach, bo jakkolwiek wiara w obecność aniołów jest czymś oczywistym (sondaż Galluppa przeprowadzony w 1992 roku podaje, że w anioły wierzyło $72 \%$ amerykańskiej młodzieży, w przypadku warunków polskich badania I. Borowika i W. Pawluczuka z roku 1990 wskazują, że w anioły wierzyło $45 \%$ respondentów ${ }^{16}$ ), aktualne obserwacje oraz wywiad na temat życia religijnego polskiego społeczeństwa donoszą, że wiadomości dotyczące bytów anielskich wymagają istotnego rozszerzenia ${ }^{17}$, tym bardziej, że są warunkiem niezbędnym w powodzeniu wyżej zaproponowanej metody.

\section{Aniołowie - wychowawcy i duchy opiekuńcze}

Każdy człowiek podlega opiece poszczególnych aniołów.

Teodoret z Cyru ${ }^{18}$

Anioł - gr. aggelos, hebr. angelus - ,posłaniec”, ,zwiastun”, to nie imię własne, lecz nazwa funkcji ${ }^{19}$. Według św. Augustyna, słowo to stanowi określenie zadania, nie postaci jako takiej. „Pytasz jak się nazywa ta natura? - Duch. Pytasz o funkcję? - Anioł. Przez to, czym jest, jest duchem, a przez to, co wypełnia jest aniołem"20. Anioł jest tym, za pośrednictwem którego Bóg przekazuje ludziom swoje przesłanie. Aniołowie są Jego posłańcami. Kierują uwagę ludzi w stronę Boga i Jego tajemnicy ${ }^{21}$ - , pełnią funkcje dane im od Boga lub są formami Jego istoty znajdującymi się poza zasięgiem naszego rozumu" C. Westermann ${ }^{22}$.

Aniołowie to duchy czyste, których zadaniem jest gloryfikowanie Boga - Jego piękna, miłości i mądrości. Są nieśmiertelni, wolni i dysponują poznaniem przewyższającym możliwości człowieka ${ }^{23}$. Poprzez aniołów Bóg ukazuje ludziom Swoją uzdrawiającą bliskość, w nich konkretyzuje się Jego obecność staje się czymś doświadczalnym² ${ }^{24}$.

${ }^{16}$ Zob. I. Borowik, dz. cyt., s. 117, 183.

${ }^{17}$ Zob. P. O’Sullivan, Wszystko o aniołach, tłum. H. Dymel-Trzebiatowska, Gdańsk 2001, s. 13.

${ }^{18}$ Zob. In Genesim 1, 2, PG 80 B, cyt. za: S. Longosz, Opiekuńcza funkcja Aniołów w nauce Ojców Kościoła. (Zarys problemu), w: H. Oleschko (red.), Księga o Aniołach, s. 185.

${ }^{19}$ Zob. H. Oleschko, Aniołów dyskretny lot, s. 11; M. Fryszkiewicz, dz. cyt., s. 19.

${ }^{20}$ Zob. św. Augustyn, Objaśnienie Psalmów, 103, 1, 15; Patrologiae Latinae 37, 1348-1349, (cyt. za: Z. Kijas, Poczatki świata i człowieka, Kraków 2004, s. 207).

${ }^{21}$ Zob. A. Grün, dz. cyt., s. 11, 14.

${ }^{22}$ Zob. K. Scherer, dz. cyt., s. 66.

${ }^{23}$ Zob. M. Fryszkiewicz, dz. cyt., s. 19.

${ }^{24}$ Ojciec A. Grün w książce Każdy ma swojego anioła tłumaczy, że obecności tej można doświadczyć na przykład przez dobre natchnienie, myśl, która popycha w stronę dobrego. W świe- 
Jako niematerialni, nie podlegają ludzkiej percepcji, dlatego też objawiając się przyjmują postać, którą ludzkie zmysły oraz świat pojęć są w stanie zaakceptować. Żyjący w XX wieku mistyk - ojciec Lamy miał dar obcowania z tymi świętymi duchami. Pytany o ich wygląd mówił, że ,wyglądają jak oficerowie w pełnej gali”, zawsze mają postać młodzieńców, a na ich twarzach niezmiennie maluje się życzliwość. Choć są ich tysiące, każdy z nich posiada swój charakterystyczny wygląd. „Są z nami, wokół nas. [...] Choć ich nie widzimy, niemniej są. Niezwykle piękni w każdym detalu, [...] co mają pięknego, to złote gwiazdy nieregularnego kształtu, rozłożone w mozaikę na wysokości ciała i ubrania. Jedna płytka gwiaździsta tu, druga tam. Taka przeplatanka z gwiazdek. Otrzymują światło Boże. Rękawy ich tunik sięgają pół ramienia, tuniki aż do kolan. Niższa cześć ciała przybrana w pewien rodzaj spódniczki - wyglądają jak atleci. Szaty ich są białe, ale białością, która nie ma nic ziemskiego. [...] biel ta jest o wiele przyjemniejsza dla oka. [...] ci święci są otoczeni światłem tak różnym od naszego, że potem wszystko wydaje się cieniem"25.

Święta Brygida opisuje, że gdyby człowiek mógł zobaczyć anioła w całym blasku jego urody, umarłby z nadmiaru szczęścia, natomiast święty Anzelm mówi, że trudno znieść bijący od niego blask. W innych opisach aniołów często autorzy posługują się porównaniami zapożyczonymi z przyrody: ogień, błyskawica, śnieg, burza, grzmot, słońce. R. Otto, definiując zjawisko sacrum, posłużył się zwrotem mysterium tremendum, mysterium fascinans. Te właśnie słowa najdokładniej oddają kwintesencję anielskiej egzystencji, którą jest groza i siła, a równocześnie fascynujące piękno i moc.

Aniołowie stoja przed Bogiem i oglądają Go twarzą w twarz. Jak metal w kontakcie z ogniem nabiera jego cech, tak aniołowie stają się zwierciadłem Boskich doskonałości: miłości, piękna, świętości, wszechmocy. Nie ma w nich żadnej niedoskonałości ${ }^{26}$. Nie doświadczają narodzin ani śmierci, wyjaśniają wolę Boga i oznajmiają Jego dzieła, obdarzają odwagą. Sa postami innej, głębszej rzeczywistośsi ${ }^{27}$.

Święty Jan Chryzostom zapewnia, że „,całe powietrze wypełnione jest aniołami. Podobnie uważa także Newman: Żyjemy otoczeni światem duchów, z którymi, choć nieświadomi tego, jesteśmy w kontakcie" ${ }^{28}$. Te duchy żyja, działaja, słyszą, patrza, kochają. Troszczą się o sprawy kosmosu, lecz w sposób szczególny opiekują się człowiekiem ${ }^{29}$.

tle tradycji chrześcijańskiej mówi się, że została ona zainspirowana właśnie przez anioła. Zob. A. Grün, dz. cyt., s. 11-13.

${ }^{25}$ Zob. M. Fryszkiewicz, dz. cyt., s. 25, 43.

${ }^{26}$ Tamże, s. 43.

${ }^{27}$ Zob. A. Skowronek, Aniołowie sq wśród nas. Fascynacje - Dociekania - Wierzenia, Warszawa 2001, s. 14.

${ }^{28}$ Cyt. za: G. Huber, dz. cyt., s. 103.

${ }^{29}$ Forma ich ,zatrudnienia” zależy od posiadanej doskonałości. Służenie ludziom jest jedną z nich. 
Bóg czuwa nad stworzeniami niższymi za pośrednictwem bytów doskonalszych, dlatego „Przy boku każdego stoi anioł jako wychowawca i pasterz kierujący jego życiem” 30 - pisze św. Bazyli. „Opatrzność Boża nie opuszcza nas w naszej słabości, ale umieszcza obok każdego z nas anioła o niecielesnej naturze dla zabezpieczenia nas w życiu. [...] Anioł ten może być nazwany bratem człowieka" - twierdzi św. Grzegorz z Nyssy ${ }^{31}$.

W 23 rozdziale Księgi Wyjścia autor natchniony pisze: „Oto Ja posyłam anioła przed tobą, aby cię strzegł w czasie twojej drogi i doprowadził cię do miejsca, które ci wyznaczyłem. Szanuj go i bądź uważny na jego słowa" (Wj 23, 20-21). Takie słowa skierował Bóg do Mojżesza na górze Synaj. Ich rolą było uświadomienie ludziom, że nie tylko człowiek jako jednostka, ale także każda wspólnota - w tym wypadku Naród Wybrany - posiadają swego anioła, który się nią opiekuje. „Miłość Boga jest bezwarunkowa i dlatego ten dar towarzysza drogi otrzymuje każdy człowiek" ${ }^{\prime 2}$.

Innym pięknym przykładem mówiącym o trosce Boga, która wyraża się poprzez obecność anioła, jest historia opisana w Księdze Tobiasza. Starotestamentowy Tobiasz wysyła swego syna - także Tobiasza, w daleką drogę, by odebrał w jego imieniu złożony niegdyś w odległej Medii depozyt. W tym celu szuka dla niego odpowiedniego przewodnika. Zostaje nim sam archanioł Rafał, który przyjął ludzką postać i podał się za ich krewnego. Było to możliwe, ponieważ byli oni ludźmi bardzo religijnymi, a Bóg czuwa nad tymi, którzy wzywają Jego imienia. W czasie podróży anioł wykazuje się nadzwyczajną wiedzą. Takie są właśnie jego interwencje, podczas których ratuje on życie młodemu Tobiaszowi, doprowadza do szczęśliwego ożenku z piękną córką Raguela i zdradza młodzieńcowi sposób pokonania demona. W czasie, gdy ten cieszy się swoim szczęściem małżeńskim, odbiera $\mathrm{w}$ jego imieniu i z upoważnienia będący celem wyprawy depozyt, następnie wraca z nim, by Tobiasza wraz z żoną bezpiecznie odprowadzić do domu jego ojca. Przywraca wzrok staremu Tobiaszowi i dopiero wtedy wyjawia swoją tożsamość: ,ja zostałem posłany, aby cię wypróbować. Równocześnie posłał mnie Bóg, aby uzdrowić ciebie i twoją synową. Ja jestem Rafał, jeden z siedmiu aniołów, którzy stoją w pogotowiu i wchodzą przed majestat Pański. [...] To, że byłem z wami, nie było moją zasługa, lecz było z woli Bożej. Jego uwielbiajcie przez wszystkie dni i Jemu śpiewajcie hymny!" (Tb 12, 11-15. 18).

Interwencje anielskie są tym, co pozwala ludziom zrozumieć wielkość i miłosierdzie Boga, bo aniołowie nie działają przez siebie i dla siebie, ale przez Boga i dla Boga. Czynią cuda jako narzędzia w ręku Boga, nigdy własną mocą ${ }^{33}$. Anioł jest tym, który przewyższając człowieka swoim rozumem, sposobem bycia, wolą, potęgą a także dzięki znajomości rzeczy przyszłych koniecznych, prze-

\footnotetext{
${ }^{30}$ Zob. M. Fryszkiewicz, dz. cyt., s. 60.

${ }^{31}$ Zob. Vita Moysis II, 45 i 47, (cyt. za: S. Longosz, dz. cyt., s. 185).

${ }^{32}$ Zob. A. Skowronek, dz. cyt., s. 16, 47, 148.

${ }^{33}$ Zob. M. Fryszkiewicz, dz. cyt., s. 26, 31.
} 
strzega ludzi przed grożącym im niebezpieczeństwem, uprzedza o ewentualnych stratach, ratuje ludzkie zdrowie i życie. Czyni to wszystko za pomocą natchnień, oddziałując na zmysły, system nerwowy i wyobraźnię - bardzo często w snach. Tak też dociera do umysłu człowieka, aby go oświecić, gdyż mimo jego różnych genialnych osiagnięć poznanie anioła będzie zawsze doskonalsze ${ }^{34}$.

Biblia uczy, że to Bóg jest źródłem najgłębszej prawdy oraz najwyższej znajomości wszechrzeczy. Anioł, będąc czystym duchem, obcuje z Bogiem i tak ogląda to nieskończone źródło Prawdy. W taki sposób poznaje wszelkie tajemnice filozofii, istotę wszechświata, własności żywiołów, a także przymioty istot rozumnych i nierozumnych ${ }^{35}$. Ojciec O'Sullivan pisze, że będąc nawet najbardziej utalentowanymi pedagogami nie jesteśmy w stanie przekazać wiedzy tak, jak potrafią to czynić aniołowie. Warto więc prosić ich o pomoc, bo oni chętnie jej udzielają. Oni także są zdolni obdarzyć uczniów miłością i pasją do nauki, a te czynniki są przecież najlepszą gwarancją przyswajania wiedzy.

„W rzeczywistości aniołowie pozostają niepojętą dla naszego rozumowania siłą" - pisze G. Gloege ${ }^{36}$. Miejsce zajmowane przez anioła mierzy się jego działaniem. Ma on zdolność błyskawicznego pokonywania przestrzeni i odległości ${ }^{37}$. Bóg poprzez swoich niewidzialnych pracowników zarządza ruchem wszechświata, wszystkimi zjawiskami oraz siłami przyrody. Św. Tomasz z Akwinu uczy, że każda gwiazda - planeta, słońce, ciało niebieskie posiada swego anioła stróża. Ma go tym bardziej najważniejszy z całego stworzenia człowiek.

\section{Anioł stróż - strażnik każdego człowieka}

Bóg zestat aniołów do strzė̇enia i pielęgnowania ludzi. Laktancjusz $^{38}$.

Aniołowie są przewodnikami i opiekunami ludzi - zwłaszcza anioł stróż. Jest on uosobieniem Opatrzności, czyli troski Boga w stosunku do każdego człowieka. Jego zadaniem jest usuwać wszystko to, co mogłoby przeszkadzać człowiekowi w realizowaniu celu, do jakiego został stworzony ${ }^{39}$. Każdy z ludzi posiada swojego anioła stróża. Bóg udziela takiemu aniołowi szczególnej miłości, by mógł on wykonywać swoją rolę jak najlepiej, nie z poczucia obowiązku, ale na skutek osobistej relacji do swego podopiecznego. Anioł stróż radzi, ostrze-

\footnotetext{
${ }^{34}$ Tamże, s. 66.

${ }^{35}$ Tamże, s. 26.

${ }^{36}$ Zob. K. Scherer, dz. cyt., s. 66.

${ }^{37}$ Zob. M. Fryszkiewicz, dz. cyt., s. 33.

${ }^{38}$ Cyt. za: M. Fryszkiewicz, dz. cyt., s. 56.

${ }^{39}$ Zgodnie z nauką Kościoła katolickiego jest to powrót do Boga.
} 
ga, podsuwa dobre myśli i pobudza do dobrego działania. Otwiera jego oczy na drogę, którą ten powinien kroczyć w swym życiu. Niekiedy dotyka karami jako środkami leczniczymi - identycznie jak ziemski pedagog. Środki te czynią ból, ale w taki sam sposób odsuwają od zła. Św. Augustyn pisze: „było odpowiednim, by aniołowie do strzeżenia człowieka byli wyznaczeni, przez których ludzie byliby pobudzani i kierowani do dobrego”. Doktryna Kościoła katolickiego głosi, że anioł stróż prowadzi po śmierci duszę, którą się opiekował do nieba, a jeśli to konieczne do czyśćca, gdzie odwiedza ją w czasie pobytu i pociesza ${ }^{40}$.

„Anioł stróż to byt $\mathrm{z}$ innej przestrzeni, który przychodzi w chwili niebezpieczeństwa, by powiedzieć zagrożonemu, że nie jest sam, że jest z nim ktoś, kto pragnie jego zbawienia, kto chce, aby żył" - Ch. Blumchardt ${ }^{41}$. Tylko nadzwyczajną interwencją anioła można niekiedy wytłumaczyć częste wypadki cudownych ocaleń dzieci w latach ich jeszcze nierozwiniętego instynktu samozachowawczego. W miarę dorastania oraz wzrostu umiejętności przewidywania niebezpieczeństw interwencje aniołów wydają się coraz rzadsze, nie oznacza to jednak, że przestali się oni w dalszym ciagu martwić o taki kształt życia swych podopiecznego, który będzie pomagał im żyć bliżej Boga. Także w życiu ludzi dorosłych występują przykłady niezwykłych ocaleń oraz wyborów słusznych rozwiązań, właśnie dlatego, że działali oni posłuszni wewnętrznemu impulsowi, który trudno wytłumaczyć w racjonalny sposób ${ }^{42}$. Anioł jest tym, który niejednokrotnie inspiruje ludzkie działanie, obecność jego jest jednak dyskretna i nienarzucająca się. Nie ma chwili ani miejsca, by anioł zapomniał o człowieku, choć o tym drugim nie można tego samego powiedzieć...

Żadna ziemska miłość, nawet miłość rodziców, nie przekracza miłości anioła, bo miłość ta sięga źródła wszelkiej miłości - serca Boga. „Miłość anioła do człowieka jest jasna, czysta, mocna, stała; nie podlega chwiejności, przerwie, zapomnieniu i w ogóle niewierności. Miłość anioła wypływa bowiem z miłości Boga do ludzi i z tej miłości czerpie stałość i najwyższą bezinteresowność" ${ }^{33}$. Anioł odnosi się do człowieka z najwyższą życzliwością - ona wypływa właśnie z tego źródła, jakim jest Bóg. Miłość anioła jest bezinteresowna i idealna, a opieka czuła. Aniołowie kochają cata intensywnościq swojej natury. Jedynym ludzkim uczuciem, które daje wyobrażenie na temat miłości aniołów, jest miłość macierzyńska, ponieważ jest ona najczystsza, najhojniejszą i najsilniejszą z ludzkich miłości ${ }^{44}$. Tak właśnie kocha anioł. Dla niego szczęściem jest szczęście człowieka. „Anioł to doskonały sługa, przynoszący człowiekowi łaskę oraz miłość Boga. Służy człowiekowi, kochając go ze wszystkich sił" - Bernard z Clairvaux ${ }^{45}$.

\footnotetext{
${ }^{40}$ Zob. M. Fryszkiewicz, dz. cyt., s. 61, 62; A. Grün, dz. cyt., s. 6.

${ }^{41}$ Zob. K. Scherer, dz. cyt., s. 67.

${ }^{42}$ Zob. M. Fryszkiewicz, dz. cyt., s. 63.

${ }^{43}$ Zob. G. Huber, dz. cyt., s. 101.

${ }^{44}$ Zob. P. O'Sullivan, dz. cyt., s. 12.

${ }^{45}$ Zob. H. Oleschko, Aniołów dyskretny lot..., s. 122.
} 
„Aniołowie są płonącym ogniem miłości, przepełnionym ogromem szczęścia. [...] Są niewypowiedzianie serdeczni. Są żywymi replikami Boga". Poznając lepiej aniołów ludzie stają się im podobni i zaczynają promieniować nadprzyrodzonym pięknem ${ }^{46}$. Powinni pamiętać o tym zwłaszcza pedagodzy, gdyż dzieci pragną towarzystwa aniołów i oczekują, że będzie nim dla nich zwłaszcza ta tak ważna w ich życiu postać - nauczyciel.

Akty miłości są tym, co upodabnia nas do Boga i aniołów ${ }^{47}$. Aby dać, trzeba wpierw mieć. Podobnie jest w przypadku miłości. Żaden z ludzi nie jest w stanie obdarzyć drugiego człowieka miłością nieposiadając jej. Nawet najlepiej wykształcony pedagog nie jest w stanie objąć swoich podopiecznych miłością, jeśli brakuje jej w jego sercu. Św. Paweł pisze w I Liście do Koryntian: „Gdybym mówił językami ludzi i aniołów, a miłości bym nie miał, [...] byłbym niczym" (1 Kor 13, 2). Zdanie to uwypukla dobitnie prawdę, która mówi, że WIEDZA BEZ MIŁOŚCI NIE MA ŻADNEGO ZNACZENIA ${ }^{48}$. Uczucia oraz postawy nie istnieją same z siebie, lecz wymagają kształcenia. Także miłość podlega tym prawom i wymaga, by dbać o jej rozwój. Doświadczenie pokazuje, że w tym zakresie potrzeb najskuteczniejszym środkiem jest ten, który nakazuje odwołać się do źródła głębi miłości. Reprezentują ją właśnie aniołowie, gdyż jak pisze E. Swedenborg: „są oni postaciami miłości Boga"49. Żaden pedagog nie powinien lekceważyć tego źródła, albowiem jest ono niezawodne.

„Nauka Kościoła o aniołach jest piękna i kojąca, jednak niestety wielu chrześcijan posiada ubogą wiedzę o wielkim świecie aniołów" - pisze ojciec O'Sullivan ${ }^{50}$. Nie zdając sobie sprawy $\mathrm{z}$ ich obecności, ludzie tracą tysiące błogosławieństw, którymi mogliby się cieszyć - „,i wszechmocni i kochający protektorzy zapewniają nam taki stopień szczęścia, na który bez ich udziału nie mielibyśmy co liczyć" ${ }^{51}$.Także ojciec Lamy zwykł był zwracać uwagę na to, że ludzie nie przywiązują do aniołów takiej wagi, jak te na nią zasługują. „Zbyt mało modlimy się do nich. Aniołowie są niezwykle poruszeni, gdy kierujemy do nich modlitwę. Mądrze postępujemy modląc się do nich. [...] Ich łaska w stosunku do nas jest olbrzymia, a my z niej wystarczająco nie korzystamy. Traktują nas jak braci w potrzebie. [...] Nie fatygujemy ich tak, jak tego oczekują ${ }^{52}$. [...] Aniołowie są bardzo wzruszeni, gdy my ich prosimy. [...] Ich miłosierdzie względem nas jest tak wielkie, a często nie korzystamy zeń dostatecznie. Patrzą na nas jak na potrzebujących pomocy braciszków"53.

${ }^{46}$ Zob. P. O’Sullivan, dz. cyt., s. 48, 49, 51.

${ }^{47}$ Zob. H. Oleschko, Aniołów dyskretny lot..., s. 213.

${ }^{48}$ Zob. M. Fryszkiewicz, dz. cyt., s. 26.

${ }^{49}$ Cyt. za: A. Grün, dz. cyt., s. 103.

${ }^{50}$ Zob. P. O'Sullivan, dz. cyt., s. 13

${ }^{51}$ Tamże, s. 11, 13, 14.

${ }^{52}$ Tamże, s. 43-44.

${ }^{53}$ Zob. M. Fryszkiewicz, dz. cyt., s. 101. 
Aniołowie są najlepszymi doradcami ${ }^{54}$ - anioł stoi najbliżej dziecka, więc może on podpowiadać rodzicom, jak oni powinni je prowadzić. Jeśli są oni wrażliwi i słuchają ${ }^{55}$ anioła dziecka, czują wtedy, co jest dla niego dobre - „co stanowi o jego niepowtarzalności i jaką przestrzeń powinni mu zaoferować, aby mogło żyć zgodnie z prawdziwą istotą swojej osobowości" ${ }^{36}$. Ojciec Fryszkiewicz pisze: „Ten niebieski doradca życzliwy i mądry jest nam tak oddany jak nikt na świecie"57. Im większa uległość dziecka, tym więcej rodzice dają mu dowodów swojej miłości. Wychowawca jest łagodny dla posłusznych mu i korzystających z jego rad uczniów. Podobnie jest w przypadku aniołów. Człowiek, stając się ulubieńcem anioła, poznaje jego tajemniczą piękność i tak zaczyna promieniować jego pięknem.

To, co dla człowieka dorosłego może wydawać się nie do przyjęcia, dla dziecka jest czymś oczywistym. Dzieci często rozmawiają z aniołami, bo żyją w świecie, który dla ludzi dorosłych jest niedostępny - zamknięty ${ }^{58}$. Ojciec A. Grün, korzystając ze swego bogatego doświadczenia psychologicznego, pisze, że świadomość obecności anioła posiadała w przypadku jego pacjentów w bardzo licznych przypadkach wymiar terapeutyczny. Mówili oni, że wyobrażenie anioła, który stoi obok, pomagało im w niejednej sytuacji radzić sobie z życiem. Wielu z nich obcowało w dzieciństwie z aniołami równie realnie, jak $\mathrm{z}$ lalką czy misiem ${ }^{59}$.

Świadomość, że nad dzieckiem czuwa anioł stróż, który chroni je przed niebezpieczeństwem, jest bardzo pomocna dla rodziców i opiekunów, ponieważ łagodzi ich lęk, nie zwalnia jednak z dzialań zapobieg a w c y ch, bo muszą one iść w parze. Należy samemu zadbać o to, co leży w ludzkiej gestii, niemniej zawsze będzie istniał międzyobszar, którego nie da się przewidzieć i wtedy właśnie dobrze jest powierzyć dziecko opiece jego anioła $^{60}$.

Myśl o tym, że każde dziecko posiada swojego anioła stróża, może stanowić dla rodziców ulgę, uwalniać od przesadnego niepokoju. Wielu z nich martwi się, czy wychowują oni odpowiednio swoje potomstwo, czy negatywne, niezamierzone oddziaływania $\mathrm{z}$ ich strony nie sprowadzą ich dzieci na złą drogę, czy rany, jakie zadali swym dzieciom nie okaleczą ich na zawsze. Rodzice nie mogą upilnować wszystkich dróg swoich dzieci. Często im bardziej się starają, tym większy niepokój oraz niebezpieczeństwo na nie ściagają. Doświadczają tego zwłaszcza ci rodzice, którzy pragną zachować nad swoim dzieckiem jak

\footnotetext{
${ }^{54}$ Zob. P. O’Sullivan, dz. cyt., s. 83, 84.

${ }^{55}$ Słuchać swego anioła, znaczy umieć podążać za jego głosem. Zob. A. Grün, dz. cyt., s. 71.

${ }^{56}$ Zob. A. tamże, s. 64

${ }^{57}$ Zob. M. Fryszkiewicz, dz. cyt., s. 102-103.

${ }^{58}$ Tamże, s. 102.

${ }^{59}$ Zob. A. Grün, dz. cyt., s. 6.

${ }^{60}$ Tamże, s. 23.
} 
największą kontrolę. Niepokój ten powinno raczej zastąpić zaufanie, że pomimo różnych wychowawczych ograniczeń dziecko ma szansę rosnąć zdrowo i prawidłowo się rozwijać w swojej sferze psycho-emocjonalnej, ponieważ czuwa nad nim anioł stróż $\dot{z}^{61}$.

Ludzie zdają sobie sprawę $\mathrm{z}$ istnienia łączności między tym, co widzialne a niewidzialne - to właśnie rodzi ich przekonanie o obecności anioła i daje świadomość, że nie jest się pozostawionym samemu sobie. „Człowiek nie jest ograniczony wyłącznie do tego, co widzialne i wykonalne. Jest otoczony tajemnicą" ${ }^{2}$. Ludzie często nie potrafią sobie wyobrazić obecności Boga jako takiego - wtedy On konkretyzuje się dla nich w postaci anioła. Każdy, kto mówi o aniele stróżu, wie, że pochodzi on od Boga - że to On postawił go przy jego boku. Przez niego Bóg działa w jego ludzkiej codzienności ${ }^{63}$.

Dzieci modlą się do aniołów, bo czują, że one wspierają ich wewnętrzne istnienie, dając pełnię. Także w dorosłym życiu anioł pojawia się, gdy jednostce zagraża wewnętrzny lub zewnętrzny rozpad. Jego działanie zmierza zawsze w kierunku integracji i pełni ${ }^{64}$. On tłumaczy człowiekowi jego życie i wpływa nań w sposób uzdrawiający i pomocny. Świadomość obecności anioła koi lęk przed zadaniami, które należy wykonać, a które mogą nie powieść się... ${ }^{65}$ : „To on pozwala mi widzieć wszystko nowymi oczyma i sprawia, że pod moimi nogami lazur niebieski miesza się z tą surową drogą. To on wydobywa dla mnie ze wszystkich rzeczy pełnię sensu i hymn wdzięczności i sprawia, że wszystko po mojej prawicy i lewicy zamienia się w rytm, ideę, podobieństwo, zdanie, słowa pełne uczuć i hymn" ${ }^{66}$ - tak wielki katolicki poeta P. Claudel przedstawia tajemnicę promieniowania anioła na człowieka, psychologia zaś mówi, że „wyobrażenie anioła stróża kontaktuje człowieka $\mathrm{z}$ obronnymi siłami jego podświadomości. Pomaga mu w tym, by bardziej na siebie uważał oraz by poddawał się życiu w sposób mniej obarczony strachem"67.

Protestancki kapłan i psychoterapeuta H. Hark w swojej terapii posługuje się wyobrażeniami anioła w kontekście jego duchowych energii, które posiadają siłę przezwyciężania i uzdrawiania autodestrukcyjnych wzorców życiowych. Twierdzi on, że wiara w anioła jest tym, co pozwala człowiekowi odkryć w sobie samym uzdrawiające energie, jest tym, co go chroni. „Anioł stróż - pisze H. Hark - jest czymś więcej niż tylko dziecinnym wyobrażeniem rozkosznego aniołka, który mi wszędzie towarzyszy. Jeśli będziemy w niego wierzyć również jako ludzie dorośli, nie tylko pokonamy nasze lęki przed codziennymi niebez-

${ }^{61}$ Tamże, s. 7, 22.

${ }^{62}$ Tamże, s. 25.

${ }^{63}$ Tamże, s. 24, 25, 26.

${ }^{64}$ E. Stubbe, Die Wirklichkeit der Engel in Literatur, Kunst und Religion, München 1993, s. 276 (cyt. za: A. Grün, dz. cyt., s. 16).

${ }^{65}$ Zob. A. Grün, dz. cyt., s. 24.

${ }^{66}$ Sermon d'Oxford sur le monde invisibile (cyt. za: G. Huber, dz. cyt., s. 103).

${ }^{67}$ Zob. A. Grün, dz. cyt., s. 25. 
pieczeństwami $\mathrm{w}$ drodze oraz przed groźnymi chorobami. On [...] przekazuje nam także poczucie, że z naszych osobistych kryzysów wychodzimy wzmocnieni" ${ }^{68}$, albowiem anioł stróż jest tym, który pomaga żyć własnym życiem i wyrwać się z roli ofiary - tym, który dodaje odwagi, by wziąć los we własne ręce i zadbać o siebie ${ }^{69}$.

\section{Wnioski}

Anioła poznaje się dopiero wtedy, kiedy obok nas przeszedt M. Buber ${ }^{70}$

Dla dziecka anioł jest wyobrażeniem czystej miłości, uosobieniem przeczucia zdrowego świata. Dla wielu dzieci wiara w jego świetlistą oraz radosną obecność jest warunkiem przeżycia. Tylko dlatego potrafią poradzić sobie z rozpaczą i nędzą dnia codziennego, gdyż anioł zwiastuje im radość ${ }^{71}$.

Dzieci często czują się nierozumiane przez swoich rodziców, nie potrafią sobie poradzić z tym, co je otacza, bo wszystko, co czynią, jest krytykowane. W takich momentach anioł jest dla dziecka tym, który pozwala doświadczyć mu szczęścia. Jego obecność sprawia, że w jego życiu pojawia się nowy horyzont. Dzieci, nie zastanawiając się wiele nad tym, szukają miejsc, gdzie ich życie łączy się z właśnie takim szczęściem. To pozwala im ujrzeć wszystko w innym świetle. „Dzięki skierowaniu spojrzenia na tego typu «doświadczenie anielskie i anielskie miejsca», może zrodzić się w nich nowe poczucie ufności"72.

Często dzieci boją się nocy i snów, które nie zawsze są kolorowe. Ważne $\mathrm{w}$ takim momencie jest, aby rozmawiać $\mathrm{z}$ dzieckiem językiem jego snu i uświadomić mu, że anioł będzie nad nim stale czuwał - nie dopuści do tego, by włos spadł mu z głowy i obudzi je w odpowiednim momencie. W takich przypadkach bardzo pomagają zawieszone nad łóżkiem obrazki anioła ${ }^{73}$.

Życie w dysfunkcyjnych rodzinach to piekło. Można je przeżyć właśnie dzięki świadomości obecności anioła, bo jest on tym, który sprawia, że dziecko może inaczej spojrzeć na świat dzięki fascynacji pięknem kawałka murawy lub też radości płynącej z widoku motylka, który właśnie przysiadł na kwiatku ${ }^{74}$. Mało kto z dorosłych potrafi zachwycić się rzeczami tego rodzaju. Dziecko, które nie

\footnotetext{
${ }^{68}$ Tamże, s. 27-28.

${ }^{69}$ Tamże, s. 45, 59.

${ }^{70}$ Cyt. za: A. Skowronek, dz. cyt., s. 9.

${ }^{71}$ Zob. A. Grün, dz. cyt., s. 108-110.

${ }^{72}$ Tamże, s. 31.

${ }^{73}$ Tamże, s. 115.

${ }^{74}$ Tamże, s. 39.
} 
zatraciło jeszcze realności wymiaru ponadmaterialnego, jest w stanie dostrzec ich niezwykłość i czerpać z nich radość. Grün pisze, że anioł staje przy boku dziecka, by samo rozwinęło w sobie strategie, które pomogą mu się uwolnić ze stresogennych sytuacji. On podpowiada dziecku, by w odpowiedni dla siebie sposób wykorzystało posiadaną siłę i mogło przetrwać trudny moment, on również kieruje dziecko w stronę walki o swój obszar wolności - o siebie samo ${ }^{75}$.

„Tylko ten, kto ufa w istnienie Bożych aniołów w swoim życiu, rzeczywiście dozna ich obecności" - pisze K. Scherer ${ }^{76}$. Przede wszystkim matki powinny zakorzeniać w umysłach swoich dzieci żywe, jasne i trwałe poczucie obecności aniołów, tak aby wyobrażenie na temat ich niebiańskich opiekunów nie było płytkie i mgliste, lecz by umiały one zwracać się do nich ze swoimi obawami i kłopotami. Pedagodzy powinni je ku temu zachęcać i przypominać o tym, gdyż jest to zdecydowanie lepsze rozwiązanie, niż nabijanie dzieciom głów lękiem przed duchami i straszydłami, a nie jest to rzadką praktyką. Dzieci już od najmłodszych lat powinny być wychowywane w duchu miłości i przyjaźni w stosunku do aniołów. Świadomość, że obok stoi ktoś kochający i dysponujący nadprzyrodzonymi możliwościami, to inwestycja dająca kapitał w postaci poczucia wewnętrznego bezpieczeństwa, owocujący przez wszystkie lata życia.

Zadaniem anioła jest uczyć człowieka odzyskiwać pokój, trwać w nim pomimo ustawicznych przemian. ,Jest to bez wątpienia wielki brak w wychowaniu ludzi do pokoju [...], do życia i działania w pokoju, kiedy zapomina się o zawsze bliskiej, wiernej i zawsze pomocnej obecności naszego anioła stróża i aniołów tych ludzi, których wychowujemy i za których jesteśmy odpowiedzialni. Niestety, [...] tak mało mówi się dzisiaj o roli aniołów stróżów, tak słabo przygotowuje się ludzi do przyjaznej zażyłości z tymi najwierniejszymi przyjaciółmi, danymi nam przez Boga na całe życie" 77 .

Anioł to bezpieczeństwo, piękno, nadzieja i lekkość. Daje oparcie i pozwala doskonalić się w tym, co dobre. Wprowadza w postawy, które pozytywnie wpływają na ludzkie życie. Wzbudza w ludziach to, o czym oni zapominają lub zaniedbują w wirze dnia codziennego. Jest on zwiastunem nadziei, że życie nie jest bezcelowe i że możliwym jest formowanie go na wzór „pierwotnego obrazu"78 - wzoru piękna i dobra, jaki zakodował w każdym człowieku Bóg. Tutaj pojawia się propozycja skierowana zarówno do ucznia, jak i jego wychowawcy, by każdy z nich samodzielnie wyszukiwał sobie anioła, który będzie mu towarzyszył w najbliższym tygodniu, miesiącu lub roku życia w pracy nad sobą, to znaczy nad rozwojem konkretnej z cnót: miłości, prawdomówności, wdzięczności, oddania, cierpliwości, otwartości, męstwa, ciepła, przebaczenia, wytrwałości, głębokiego

${ }^{75}$ Tamże, s. 59.

${ }^{76}$ Zob. K. Scherer, dz. cyt., s. 69.

${ }^{77}$ Zob. G. Huber, dz. cyt., s. 146.

${ }^{78}$ Zob. A. Grün, 50 aniołów na cały rok. Ksiażka pomagajaca ksztaltować nasze wnętrze, thum. A. Makowska, Kielce 2002, s. 10. 
szacunku, zrozumienia, spokoju, łagodności, tolerancji, posłuszeństwa itp. Należy prosić anioła, by pozwolił zobaczyć to, co najlepsze w sobie i innych, by umieć lepiej obchodzić się z sobą i z innymi ${ }^{79}$.

Anioł koi tęsknotę za światem, w którym panuje bezpieczeństwo i delikatność, piękno oraz nadzieja. Objawia ludziom głęboką prawdę - pokazuje, że ludzkie życie jest „czymś więcej” i że liczą się w nim także duchowe wartości, a ich obecność jest tym, co sprawia, że życie wypełnia inny, lepszy smak - smak, który tuli tęsknotę duszy ${ }^{80}$.

\section{Angel as a Former-Teacher Guide}

(Summary)

Knowledge about angels constitutes an integral part of Christian doctrine deposit. In light of sociological studies the range of faith in angels is much more higher than in the case other biblical persons. These studies prove that this faith is an inherit need of human.

The role of angel is to be guide and guardian of people. The role of former-teacher is the same.

The author of this article wants to inspire to develop consciousness about angels's presence and informs about educational consequences of this knowledge, which can be very useful for all these former-teacher who want to help their foster-children in sincere way.

\footnotetext{
${ }^{79}$ Tamże, s. 10, 11, 15.

${ }^{80}$ Tamże, s. 8.
} 